УДК 398. 85: 355

Мельник Н. Г., кандидат філологічних наук, доцент кафедри української та світової літератур Криворізький державний педагогічний університет

\title{
НАРОДНІ ПІСНІ ВІЙСЬКОВОЇ ТЕМАТИКИ КРІЗЬ ПРИЗМУ КАТЕГОРІЙ ТРАГІЧНОГО ТА ГЕРОЇЧНОГО
}

У статті досліджується проблема відображення в козачьких та солдатських піснях народних уявлень про трагічне та героїчне. Акиентовано на трансформації етикоестетичної конщепції національного героя, від «національного морального кодексу» активної суспільної одиниці (козака як ідеального типу) до пасивної ролі особистості в державі та суспільстві. Козацьке трактування смерті підпорядковане розумінню військової діяльності як необхідної, продиктованої начіональними потребами «героїчної» доби, як закономірного результату активного, динамічного життя особистості, свідомо готової до 
самопожертви. Трагічна сутність иьвого явища в фольклорній свідомості набирає нових етико-естетичних ознак, щзо продиктовані розумінням козацькою верствою особливої ролі людини в суспільстві, її моральної відповідальності, естетикою патріотизму.

Рекрутське, солдатське сприйняття смерті продиктоване ставленням до воєнної служби як до дисгармонійної, нелогічної, неприродної, непотрібної.

Ключові слова: козак, рекрут, солдат, трагічне, геройчне

В статье исследуется проблема отображения в казаџких и солдатских песнях народных представлений о трагическом и героическом. Акиент сделан на трансформации этико-эстетической концепџии национального героя, от «национального морального кодекса» активной сочиальной единиць (казака как идеального типа) к пассивной роли личности в государстве и обществе. Казаикая трактовка смерти базируется на понимании военной деятельности как необходимой, продиктованной начиональными требованиями «героической» эпохи, как закономерного результата активной, динамической жизни личности, сознательно готовой к самопожертве. Трагическая сущность этого явления в фольклорном сознании обретает новые этико-эстетические черты, которые продиктованы пониманием казаками особенной роли человека в обществе, его моральной ответственности, эстетикой патриотизма.

Рекрутское, солдатское восприятие смерти продиктовано отношением к военной службе как к дисгармоничной, нелогичной, неприродной, ненужной.

Ключевые слова: казак, рекрут, солдат, трагическое, герочческое.

This article analyzes the problem of reflecting in Cossack and soldiers' folk songs the perceptions of the tragedy and heroism. This paper focuses on transforming the ethical and aesthetic concept of a national hero from the "national moral code» active social person (Cossack as an ideal character) to a passive acting individual in the state and society life. Cossack death representation deals with interpreting military activities as important needs dictated by national demands of «heroic» era. It is depicted as the natural result of the active and dynamic life and person's conscious readiness for sacrificing. The tragic nature of this phenomenon in the folk songs is achieved due to new ethical and aesthetic features caused by percepting Cossacks the special role of a person in society, individual moral responsibility and patriotism aesthetics. Recruiting and soldier death perception is formed by means of certain attitude to military service as disharmonious, illogical, unnatural, unnecessary activity.

Keywords: Cossack, recruit, soldier, tragic, heroic.

\section{Дослідження системи традиційних етико-естетичних принципів $\epsilon$} сьогодні однією $з$ найактуальніших гуманітарних проблем. Пісенний фольклор є результатом осмислення, оцінювання та відображення традиційних духовних шукань народу. Він не лише зберіг традиційні уявлення про добро і зло, справедливість та несправедливість, співчуття й байдужість, прекрасне та огидне, високе й низьке, трагічне та комічне, героїчне, але й надав їм стрункості, універсальності, здатності до функціонування в різних сферах ментального життя. Тому народна пісня, що є естетичною за своєю сутністю й виражає традиційну оцінку дійсності - цінне джерело пізнання національного світогляду. 
I. Франко, Ф. Колесса, В.Гнатюк, О. Потебня, М.Сумцов, М. Гайдай, С. Грица, В. Гусєв, Н. Шумада збагатили науку цінними концепціями та окремими спостереженнями 3 цієї проблеми. Так російський учений В. Гусєв досліджує естетичний ідеал колективу на різних етапах історичного розвитку та його здатність до трансформацій. Науковець визначає ідеал народу як сукупність естетичних уподобань різних соціальних груп у різні історичні періоди, а також виокремлює поняття «естетика фольклору» [Гусев 1967:267-270]. В. Буряк указує на здатність фольклорного тексту зберігати народні уявлення про трагічне, гермонійне. На думку науковця, саме ці категорії є визначальними в традиційній естетичні концепції [Буряк 1992:35].

У сучасній гуманітаристиці, як слушно зазначає М. Дмитренко, започатковано «<...> новий сочіологічно-фольклористичний напрям вивчення суспільства через соиіум із його різноманітними локальними та професійними середовищами, масовими акиіями та подіями відповідно певними фольклорними явищами, щзо витворені під час иџих подій, супроводжують повсякденне життя малих соціальних колективів», коли «<... актуалізується вивчення не виконавия (носія, респондента під час виконання твору), тексту і контексту, а інтегроване пізнання вченими різних галузей наук фольклорних елементів соиіального життя (соиіальні норми, поведінку, політику, етикет $і$ т.n.)» [Дмитренко 2014:9].

На думку I. Кімакович, «виникнення та поширення фольклорних творів стверджує той факт, що вони задовольняють певні індивідуальні потреби, декларуючи ті чи ті уявлення про світ. Разом з тим, иінності, які пропагують різні соціальні групи, завжди різнились та різнитимуться, а тому конкуруватимуть доти, доки існуватимуть різні способи буття в суспільстві. Таким чином рухається культура та духовне життя соціуму» [Кімакович 2014:31].

Саме тому сьогодні необхідний комплексний аналіз корекцій у традиційних ціннісних орієнтаціях різних соціальних типів, що сталися під вагою історичних, ідеологічних причин, представлених у народних українських 
піснях соціально-побутового циклу. Це, на нашу думку, відкриє причини світоглядних трансформацій українців, результати яких спостерігаємо в сучасному суспільстві.

Мета нашого дослідження - аналіз соціально-побутових пісень військової тематики (козацьких, рекрутських, солдатських) крізь призму категорій трагічного та героїчного. Вибір концептів трагічне / героїчне, 3 погляду яких аналізуються пісенні тексти, - невипадковий. Як правило, їх використання у фольклорному творі свідчить про звернення народу до екзистенційної проблематики. Перебуваючи на межі життя і смерті, людина стає справжньою, демонструє своє істинне розуміння цінності та смислу людського життя, тому козацька, рекрутська та солдатська пісня в цьому сенсі є досить ілюстративними.

Соціально-побутова пісенність як відображення глибинних внутрішніх процесів переосмислення явищ суспільного та родинного життя, ілюструє зміни світоглядних позицій. Текстологічна близькість (спорідненість у стилі, формі, фразеологічна подібність) козацьких та рекрутських, солдатських (жовнірських) пісень, здатність до осмислення та відображення дійсності 3 позицій різних історичних типів, зумовлюють формування цілісного уявлення про еволюційні процеси в свідомості народу. Ці процеси свідчать про трансформацію етико-естетичної концепції національного героя, від «національного морального кодексу» активної суспільної одиниці (козака як ідеального типу) до пасивної ролі особистості в державі та суспільстві, яка, на думку багатьох науковців, може призвести до духовного, політичного, економічного занепаду нації загалом.

Козацьке сприйняття смерті як фатальної необхідності, логічного завершення військового життя продиктоване естетикою патріотизму, осмисленням підпорядкованості власного життя національній ідеї. Ідучи на війну, козак розуміє, що за своє коротке життя не здобуде значних матеріальних цінностей. Та й не заради цього він живе. Сдиною заслугою $є$ славна смерть заради великої мети: 
Ой на горі огонь горить,

А в долині козак лежить.

Накрив очі китайкою -

Заслугою козацькою

[Козацькі пісні 1969:57].

Для козака смерть на війні - почесна. Поряд із розумінням трагізму моменту в козацькій пісні звучить захоплення саме таким кінцем життєвого шляху людини, славним, гідним, на злеті духовних поривань. Змінити своє життя, відмовитись від ролі захисника, означає забути про свою сутність, зрадити собі. Гасло «каратись, мучитись, але не каятись» постає формулою життєвої концепції козака.

Смерть у пісні порівнюється 3 весіллям, могила - 3 дружиною. Такі традиційні формулине лише надають експресивності картинам смерті, а й ілюструють внутрішній зв’язок у народній свідомості між ідеями подружжя та воєнної відваги.

Наприклад:

Ой не кажи, щзо я вбився,

Але скажи: оженився.

Та взяв собі в попа дочку, -

В чистім поли могилочку.

Хорошая, прибраная,

На ній сукня зеленая [Народні пісні Хмельниччини 2014:561].

Отже, поряд із трагізмом - естетизація смерті. Через розгорнуту метафору подається модель ідеальної ситуації: дружина - дочка царя або священника; дружина - могила.

У руслі даної проблеми цікавими нам видаються спостереження, висловлені Г. Грабовичем. Аналізуючи поезію Шевченка, котрий, на думку автора, співзвучний «зі свідомими й несвідомими почуттями народу», дослідник указує на те, що в творах поета «козаки й козацька могила утворюють одну міфологічно-семантичну одиницю», визначають 
«екзистенціальний статус козацтвва на межі життя $i$ смерті» [Грабович 1998:139].

Подібним чином ці образи пов'язані у фольклорній свідомості. Власне й саме посвячення у козаки, описи якого знаходимо в історичних джерелах, містить у собі ознаки ініціаційного ритуалу, зміст якого - розрив зв'язків із попереднім життям, смерть і народження у новій якості.

3 іншого погляду використання наскрізних образів «смерть / весілля», «могила / дружина», обрядової лексики весільних пісень (старости, бояри, дружечки, світилки, молода, теща, зять і т. д.) можна трактувати як спосіб осмислення козацької долі крізь призму родинних відносин, засіб протиставлення архетипу козака образові звичайної людини.

Поряд із цим, фольклористи, етнопсихологи, історики вказують на поєднання в характері козака протилежних етичних норм та естетичних принципів, зазначають складність козацької душі. Вона поєднує у собі два світи: козацький i селянський. У монографії «Козацька християнська республіка» Д. Наливайко вважає поєднання в одній собі виробника і воїна, трудової і військової діяльності найхарактернішою рисою козацького типу. Дослідник акцентує увагу на тому, що прагнення військового життя в свідомості козака переважає над бажанням жити спокійно [Наливайко 1992:142].

Д. Донцов уважає появу в козака прагнення жити звичайним життям ознакою деградації провідної верстви та причиною розпаду держави: «<...> де віжки й батіг випадають з слабих рук дегенеруючої еліти, де замість служби високим абстрактним ідеалам приходить вільна гра самолюбних матеріальних інстинктів маси й одиницьь, погоня за насолодою, вигодою $і$ щзастям - там замість діючого морального закону, наступає ... розклад» [Донцов 1991:45]. Дослідник чітко розподіляє психічні риси, що притаманні селянинові чи козакові. На його думку, ці соціальні типи займають різні позиції в ієрархічній структурі суспільства, хоча i взаємодіють одна 3 одною. Одна каста («правляча», «благородна») захищає другу, інша («гречкосії»), - виживляє 
першу [Донцов 1991:159]. Змішування функцій різних верств, ситуація, коли «шляхетно урожоні козаки» втрачають психічні ознаки благородної касти, ведуть до загибелі духу патріотизму у суспільстві. Водночас Д. Чижевський визначає «емоціоналізм і сентименталізм, чутливість та ліризм» невід’ємними рисами психічного складу українця. Вчений також підкреслює неабияке значення для українця почуття (серця), оскільки воно $є$ одним із шляхів пізнання світу [Чижевський 1994:203].

У козацькій пісні знаходимо філософське розуміння кінцевості людського існування, сум із приводу неможливості щось змінити в цьому світі поряд із сприйняттям смерті як вищого життєвого напруження, «злету усіх сил в єдиному подихові» [Андрухович 1994:75].

Смерть, за визначенням німецького філософа В. Франкла, разом із провиною $\mathrm{i}$ болем складає «трагічну тріаду» існування людини [Франкл 1990:210].

На думку Д. Донцова, вміння витримувати будь-який фізичний біль, не боятися смерті виступають рисами шляхетної людини, яка 3 погордою ставиться до дочасних речей, оскільки «хто прив'язує перебільшену вагу до фізичного болю, той не може високо тримати поняття обов'язку $і$ честі» [Донцов 1991:166].

Козак у пісні постає людиною, яка здатна пожертвувати власним життям заради високої ідеї. Це не означає, що козак не мав страху перед смертю, а свідчить про те, що він умів той страх перемогти; не означає, що не цінував життя, свідчить про те, що заради мети вмів любов до життя перетворити на любов до смерті:

Ой на горі вогонь горить,

А в долині козак лежить,

Xa-xa-xa,

А в долині козак лежить.

А в долині козак лежить,

Коло нього коник стоїть [Народні пісні Хмельниччини 2014:562]. 
Наведений уривок із козацької пісні підштовхнув нас до цікавих роздумів. На перший погляд, вигук «ха» випадає з загальної тканини тексту. У загалом сумному епізоді, в якому козак помирає, сміх постає дещо чужорідним елементом. Проте відомо, що однією 3 функцій комічного є заперечення, невизнання чогось за норму, засудження певних рис, явищ, станів, реалій. Висміюється те, що не приймається. Великий тлумачний словник сучасної української мови також підтверджує, що вигук «ха» «<..> уживається для вираження незгоди з чим-небудь, неприйнятності чогось (іноді з відтінком іроніï)»[Великий тлумачний словник української мови 2009:1554]. У такому сенсі названий вигук постає в пісні цілком гармонійним елементом. Так, поєднуючи трагічне і комічне, через художню антитезу народ утверджує ідею перемоги життя над смертю, а твір, на перший погляд, присвячений конкретній події, набирає глибоко філософського спрямування.

Життя козака набирає значення гри зі смертю, він сам шукає іï, викликає ворогів на бій:

Гей, як крикне козаченько

до гаю, до гаю:

«Наӥжджайте, воріженьки,

сам вас накликаю!» [Соціально-побутові пісні 1985:88].

Козак, попри прохання матері залишитись, намагається, не чекаючи нападу, першим дістатися до хана («Ой доб’юся я до нього, злого бусурмана»), звоювати турка:

Не теперки, моя мати,

В гості зазивати,

Бо я їду на Вкраӥну

3 турком воювати!

Своїм тілом білесеньким

Орлів годувати,

Свою кров'ю червоною

Моря доповняти! [Козацькі пісні 1969:166].

Поряд із цим у пісні звучить надія на те, що доля сприятиме козакові: 
Ой не вернуся,

Отеиь-матуся,

Поїду на Вкраӥну:

В мене кінь вороний,

Сам я молодий,

То, кажеться, не загину! [Козацькі пісні 1969:137].

Укартинах смерті поєднані трагічнеі оптимістичне, прекрасне і натуралістичне.

М. Костомаров зазначає: «Смерть козака у колі товаришів - звичайна картина в малоруській поезї. $Є$ щуось істинно лищарське, піднесене в цүих описах» [Костомаров 1994:139]. За спостереженням Г. Нудьги, козацька смерть оспівана в народній творчості з особливою любов’ю: «Ніщуо так не оплакано на Україні, як козаџько-лицарська смерть у полі, «біля річки Самарки, біля криниці Салтанки», на долині Кодимі чи на Савур-могилі. Ïх оплакує степ, оплакують птиці, а ті дерева, під якими лежали козаки, - не бере навіть вогонь» [Нудьга 1997:41].

В. Гусєв вважаєце ознакою свідомого підпорядкування всіх засобів фольклорного твору «естетиц̧і урочистості» [Гусев 1967:40]:

Казав собі висипати високу могилу,

Казав собі посадити в голові калину.

Будуть пташки прилітати, извіт калини їсти,

Будуть мені приносити з України вісті.

Образ смерті в козацькій пісні має подвійне смислове трактування: 3 одного боку iї змальовано як несподіванку (незважаючи на розуміння чоловіком небезпеки, він із оптимізмом дивиться у майбутнє, надіється на «фортуну»), 3 іншого - як логічний, фатальний результат діяльності героїчної особистості, яка, хоч і робила корисну справу, проте, не завжди дотримувалася стійких морально-етичних норм.

Козацьке життя - захоплююче, динамічне, воно не передбачає довгого спокійного життя та звичайної смерті. Козак знаходить смерть у морі, в полі, коли «три дні 3 коня не встає, з стремен ніжок не виймає», у бою. Причини 
загибелі (невчасний виїзд i зневажання прикмети-перестороги, нехтування материнським благословенням, неуважність, негідна поведінка) ілюструють народнопісенні уявлення про вплив долі на життя людини.

У багатьох випадках смерть приходить як розплата за недотримання козацьких моральних приписів (пияцтво перед боєм, зверхнє ставлення до людей похилого віку, зрада товаришам). За це від козака відвертається доля («Обізвалась доля на тім боці моря»). Структура пісні передбачає перенесення уваги слухача 3 моменту смерті на інші реалії (кінь, ворон і т. д.). Сцени поразки козака свідомо випущені. Натуралістичні сцени видирання, вибирання, висисання очей, оббирання хижими птахами та тваринами кісток створюють емоційне напруження, підсилюють трагізм ситуації. Народ захоплюється стоїчною витривалістю героя, який зневажає таку страшну смерть.

1) На кучері наступаю,

Чорні очі видзьобаю,

Білі лищя висисаю

[Соціально-побутові пісні 1985:159];

2) Біле тіло оббираю,

Жовті кістки розношаю

Oй по горах, по долинах

Та по чужих Украӥнах

[Соціально-побутові пісні 1985: 164].

За спостереженням Ю. Андруховича, змалювання смерті, «яка знімає напругу, розрубуючи найнерозв'язнімі вузли», смерті - «визволительки», смерті, «що приносить вічний спокій виклюваним очам і вибіленим кісткам», виступає найчастішим мотивом української «лицарії». Порівнюючи образи лицаря в середньовічній літературі та козака в народній пісні, дослідник розкриває смислові коди образу смерті, що домінують у фольклортворчій традиції українців, указує на ії підкреслену естетизацію: «Бо то не лиме смерть, а $\check{u}-$ вище життєве напруження, злет усіх сил в єдиному подихові, проростання 
крил. Ця велика містерія кохання і смерти, ия вистава за участю героїв не тільки міфологічних мусить подобатися Глядачеві» [Андрухович 1994:75].

Образність козацьких пісень постає джерелом поетичного стилю для творів рекрутської, солдатської, жовнірської тематики. Попри концептуальну відмінність у поглядах на військову службу козака та рекрута (солдата, жовніра), картини, що змальовують смерть на війні, - подібні.

Для козака смерть на війні - гідне завершення життєвого шляху, для солдата - лютий кінець, що позбавить його невільницького життя, повного фізичного та духовного насильства. Якщо в козацькій пісні недоля найчастіше постає як вирок за моральні гріхи, то в рекрутській (солдатській, жовнірській) приналежність до військового життя постає результатом покарання нещасливою долею.

Смерть рекрута-жовніра, змальовується як очікувана невідворотність. Настрій приреченості - провідний у рекрутській пісні.

1) Плаче мила,плаче чорними очима:

«Вечеронька на столі,а смерть за плечима!

[Соціально-побутові пісні 1985:157];

2) Ой ти кажеш, єден дурню, жовнярові добре,

Не єдиному жовнярові ворон кості дзьобле

[Коломийки 1973: №3956].

Тексти рекрутських, солдатських (жовнірських) пісень свідчать про художню трансформацію традиційних образів. Так реалії козацького побуту постають складовими елементами картин солдатської смерті. Використання козацької образності в процесі змалювання смерті рекрута, солдата, жовніра, очевидно, мало за мету викликати співчуття до їх трагічних доль, хоча

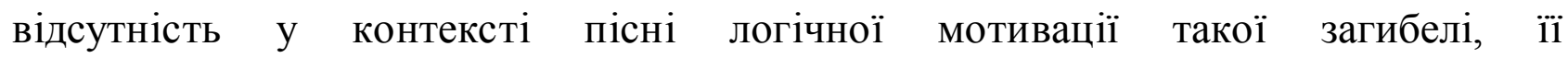
підпорядкування високій ідеї, зумовлюють певну неприродність таких художніх елементів. Зокрема, мотиви «кучерями степи устеляти», «з лоба очі видирати», хоча й не суперечать загальному настроєві, все ж, на нашу думку, є суто стильовими чинниками. 
Зокрема, поряд із реалістичними картинами солдатського побуту, опис смерті солдата часто далекий від дійсності (відсутність кучерів у солдата фактично підтверджена, оплакана в пісні 3 підкресленим драматизмом, докуменити свідчать також про своєчасне поховання солдат через необхідність дотримання правил санітарії). Солдатська реальність виключає також використання сформованих у козацькій пісенності поетичних висловів типу: «їхав поле, їхав друге, став коня попасати»; «шукай, мати, лікароньки, зеленої муравоньки» і т. ін.

Оптимістичний настрій, який знаходимо в козацьких піснях, розуміння недаремності загибелі козака, його націотворчої ролі, у творах рекрутської тематики - відсутні. Безнадія, безвихідь, приреченість - провідні категорії названих творів:

1) Eй, буде, хлопцуі, война, буде хлопичі, война,

Буде нами, молодими, сира земля повна

[Коломийки 1973: №3960];

2) Сден кричить: «Ратуйте мня!»

Другий кричить: «Добийте мня!»

Третій кричить: «Берте яму»

[Соціально-побутові пісні 1985:460-461].

Філософське ставлення до смерті у козацькому середовищі проілюстроване у заклику, який мав заохотити вступати до лицарського товариства. У ньому - концепція козацького життя і смерті: «Хто хоче за християнську віру на кілку сидіти, хто за святий хрест радий, щуоб його четвертовано $і$ колесовано, хто готовий прийняти усякі муки $i$ не боїться смерти, - приставай у козаџтво. Не треба смерти лякатися, бо від неї не встережешся. Таке життя козаче!» [Яворницький 1968:20].

За народним розумінням, людина, яка бере на себе право вирішувати долі інших людей повинна мати відповідні психічні та моральні риси, зокрема має бути готова в разі необхідності гідно померти. 3 іншого боку, наведений козацький вислів має й інший моралістичний зміст: людина, яка обирає шлях 
воїна, повинна знати, що за насильство над іншими буде покарана насильницькою смертю. За законом справедливості за гріх братовбивства обов’язково прийде кара. На розуміння цього християнського закону натрапляємо в народних уявленнях про долю людини.

За піснею, козак сподівається на щасливу долю, оскільки впевнений у тому, що живе правдиво. Гумористичний вислів «Немає в світі правди, тільки в Богові та в мені трохи» - формула, що диктує самооцінку представника цього соціального типу. Оптимізм, із яким козак сподівається на сприяння долі, загальне ставлення до служби закарбоване в словах:

Нехай вони беруть, я сі не боюся,

Кінь вороний, я молодий, іще вислужуся

[Соціально-побутові пісні 1985:214].

Коли приходить смерть, козак сприймає іï як закономірність, як завершення розкішного, вільного, справедливого життя: «Отут же нам, братці, помирати, не знатиме ні отець, ні мати». Рекрут, солдат саму службу у війську розуміє як невідворотний шлях до смерті, повільне вмирання, розтягнуте у часі, звістку про набір - як смертельний вирок.

Текстуальна тканина рекрутської пісні насичена лексемами типу «гріб», «біда», «погинути», «кості», що визначає трагічний емоційний фон та викликає в слухача відповідні зорові асоціації. Тому наявність у творах епізодів, позначених стильовими ознаками голосінь, а почасти й цілком викінчених зразків цього давнього виду народної словесності, логічно зумовлена:

1) Очі ж мої каренькї̈! Чом не глянете?

Вуста ж мої солодкії! Чом не мовите?

Ручки мої паперовії! Чом не робите?

Ніжки ж мої біленькії! Чом не ходите?

[Соціально-побутові пісні 1985:213].

Досліджуючи категорію героїчного у фольклорі та літературі, Н. Малинська приходить до висновку про логічний взаємозв'язок трагічних та героїчних маркерів ліро-епічного твору: «Можна навіть стверджувати, щзо 
героїка мотивом смерті у фольклорі та літературі остаточно $i$ найпереконливіше візується як явище доконане, про щуо, зокрема, свідчить перманентне сусідство в кобзарських репертуарах звитяжних дум із плачами та псалмами, щуо передбачає ідентичну значущість і впливовість на слухача, бо їх матричною $і$ змістовою константою $є$ урівноваження горя славою» [Малинська 2002]. [Підкреслення наше - Н. М.]

Отже, козацьке трактування смерті підпорядковане розумінню військової діяльності як необхідної, продиктованої національними потребами «героїчної» доби, як закономірного результату активного, динамічного життя особистості, свідомо готової до самопожертви. Трагічна сутність цього явища в фольклорній свідомості набирає нових етико-естетичних ознак, що продиктовані розумінням козацькою верствою особливої ролі людини в суспільстві, іiі моральної відповідальності, естетикою патріотизму.

Рекрутське, солдатське, жовнірське сприйняття смерті продиктоване ставленням до воєнної служби як до дисгармонійної, нелогічної, неприродної, непотрібної. Жорстокість, із якою ставляться до людини, нелюдський характер стосунків у війську, нерозуміння воєнних стратегічних цілей сформулювали народне уявлення про мету набору: «Поведемо їх всіх у чистеє поле, загатимо ними глибокеє море, та будемо їх м'ясом звір'є годувати, та будемо їх кров'ю nтахи напувати». Трагічне в усі часи явище «смерть» в рекрутській, солдатській інтерпретації повністю позбавлене естетичних фарб, притаманних козацькій пісенності, й постає уособленням народних уявлень про страшний, лютий кінець людини-невольника, примусово позбавленого спокійного, гармонійного мирного життя в селянському середовищі та родині.

\section{БІБЛІОГРАФІЯ}

Андрухович 1994 - Андрухович Ю. Кохання і смерть по-лицарськи: визволяння панни / Юрій Андрухович // Сучасність.- 1994. - № 1. - С. 72-75.

Буряк 1992 - Буряк В. Естетичний аспект індивідуального самовираження сучасної фольклорної пам’яті / Володимир Буряк // Записки наукового 
товариства ім. Т. Шевченка. - T. 223 (ССXXIII). Праці етнографії та фольклористики. - Львів. - 1992. - С. 33-44.

Великий тлумачний словник 2009 - Великий тлумачний словник сучасної української мови (з дод., допов. та СД) [Уклад. і голов. ред. В. Т. Бусел]. - К. : Ірпінь: ВТФ «Перун», 2009. - 1736 с.

Грабович 1998 - Грабович Г. Поет як міфотворець [Текст] / Григорій Грабович. - К. : Критика, 1998. - 206 с.

Гусев 1967 - Гусев В. Эстетика фольклора / Виктор Гусев. - М. : Наука, 1967. - C. 267-312.

Дмитренко 2014 - Дмитренко М. Фольклор: категорія жанру (критикоаналітичний огляд) / Микола Дмитренко / Український фольклор: методологія дослідження, динаміка функціонування: Колективна монографія / [за редакцією доктора філологічних наук, професора М. К. Дмитренка] - К. : ПАЛИВОДА A. B., 2014. - C. 9-20.

Донцов 1991 - Донцов Д. Дух нашої давнини / Дмитро Донцов. Дрогобич, 1991. - 342 с.

Кімакович 2014 - Кімакович I. Фольклорна свідомість в теорії естетики / Ірина Кімакович / Український фольклор: методологія дослідження, динаміка функціонування: колективна монографія / [за редакцією доктора філологічних наук, професора М. К. Дмитренка] - К. : ПАЛИВОДА А. В., 2014. - С. 21-39.

Козацькі пісні 1969 - Козацькі пісні. - К.: Музична Україна, 1969. - 295с.

Коломийки 1973 - Коломийки [упорядкув., передм. і примітки Н. С. Шумади. Нот. матеріал упоряд. 3. І. Василенко]. - К.: Музична Україна, 1973. -439 c.

Костомаров 1994 - Костомаров М. Об историческом значении русской народной поэзии / Микола Костомаров // Слов'янська міфологія. - К. : Либідь, 1994. - C. 130-154.

Малинська 2002 - Малинська Н. А. Героїчне у фольклорі та літературі. Дискурс канону : автореф. дис. на здобуття наук. ступеня докт. філол. наук : 
спец. 10.01.01 - українська література / Наталя Анатоліївна Малинська. - К., 2002. -33 c.

Наливайко 1992 - Наливайко Д. С. Козацька християнська республіка / Запорозька Січ у західноєвропейських історико-літературних пам'ятках / Дмитро Сергійович Наливайко. - К. : Дніпро, 1992. - 495 с.

Народні пісні Хмельниччини 2014 - Народні пісні Хмельниччини (з колекцій збирачів фольклору) / [Упорядкув. та вступ. статті М. К. Дмитренка, Л. О. Єфремової]; НАН України, ІМФЕ ім. М. Т. Рильського. - К. : Наук. думка, 2014. $-720 \mathrm{c}$.

Нудьга 1997 - Нудьга Г. Українська дума і пісня в світі. Книга 1. / Григоій Нудьга.- Львів: Інститут народознавства НАН України, 1997. - 424 с.

Соціально-побутові пісні 1985 - Соціально-побутові пісні [Упоряд. і передм. О. М. Хмілевської]. - К. : Дніпро, 1985. - 331 с.

Франкл 1990 - Франкл В. Человек в поисках смысла / В. Франкл. - М. : Прогресс, $1990-368$ с.

Чижевський 1994 - Чижевський Д. Український народний характер i світогляд / Дмитро Чижевський // Українозавство [посібник].- К., 1994. C. 203-213.

Яворницький 1968 - Яворницький Д. І. Україно-руське козацтво перед судом історії / Дмитро Іванович Яворницький. - Український історичний журнал. - 1968. - № 7. 